\title{
THE PRAGMATISM OF SUFFERING: AN INTERTEXTUAL STUDY OF THE BOOK OF JOB AND JOHN STEINBECK'S THE GRAPES OF WRATH
}

\author{
BENITA SAMUEL* \& Dr. FLORENCE JEYARAJ
}

Research Scholar, Department of English, Annamalai University, Chidambaram, Tamil Nadu, India

\begin{abstract}
Pain and suffering have become an integral part of man's life and existence. Those who have endured innocent or undeserved sufferings, tend to articulate their experiences in order for several reasons. One is to keep future generations reminded of history and its dark pages and another is a quest for an answer to undeserved suffering. No man has ever been able to come up with a definite answer to this most intriguing question that has baffled the meek and the mighty. Several authors have been either victims or witnesses of unjust suffering. The Book of Job in the Bible is a text that speaks of the humongous suffering of Job. His undeserved suffering has been the nucleus of many great canons by different authors belonging to different periods of time. This thought has led to the intertextual study of the Book of Job and John Steinbeck's The Grapes of Wrath analysing the pragmatics of suffering.

KEY WORDS: Intertextuality, Suffering, Identity, Pain, Resilience, Dignity, Honour
\end{abstract}

Received: Nov 04, 2020; Accepted: Nov 24, 2020; Published: Jan 08, 2021; Paper Id.: IJELDEC20204

\section{INTRODUCTION}

Suffering is an intriguing thing that has baffled the minds of great men from the beginning of times. Scholars and philosophers have made futile attempts to understand the meaning of suffering, especially undeserved suffering. Though suffering is considered and accepted as a universal reality, there has not been a single explanation of the cause of suffering. In various beliefs and traditions, there have been several ideologies proposed to understand the reality of suffering. It has been nearly impossible to analyse and accept its mysterious presence and purpose in human experience. In the present scenario, suffering is a topic of wide interest and debate. Unspeakable suffering, pain, loss, or destruction affects the body, mind, and soul immensely. Suffering has led to the writing of several popular pieces of literature by various authors across the globe. The suffering of Job in the Bible has been the most debated example of undeserved or innocent suffering.

Day in and day out we see innocent people suffer for various reasons. The loss of lives in natural disasters like tsunami, earthquakes, tornados, floods, etc. A sudden fatal medical ailment such as a five-year-old being diagnosed with cancer or any other mysterious medical anomaly would certainly fall into the category of undeserved suffering. What could be deciphered of suffering? Some scholars have said that man suffers because God has allowed it for a specific purpose known only to Him. However, this is beyond human understanding, acceptance, and tolerance. Extreme suffering could put the individual involved in a state of psychosis. R.D.Hinshelwood in his book says, "The power of psychosis renders families, friends and loved ones quite ineffective" (108). This is the effect of those who experience a psychotic condition as a result of extreme and undeserved suffering of various kinds. 
This paper deals with an intertextual study of the Book of Job and John Steinbeck's The Grapes of Wrath in order to understand the pragmatic nature of suffering.

\section{INTERTEXTUALITY}

It is essential to discuss the postmodern concept of intertextuality before making an intertextual analysis of the said texts. In order to understand intertextuality, it is imperative to also highlight the theory of postmodernism. Postmodernism is a term often applied to a set of developments in the areas of literature, critical theory, philosophy, architecture, art, and culture. Post-structural critics such as Jacques Derrida, Michel Foucault, Jacques Lacan, and Roland Barthes brought new perspectives in analysing a text. A post-structural critic uses a variety of perspectives to create a multifaceted interpretation of a text, even if these interpretations conflict with one another. Intertextuality is a theory posited by Julia Kristeva, a French Semiotician. Kristeva has been influenced by both Saussurean and Bakhtinian models and made attempts to combine their major theories.

In the mid-1960s the French intellectuals were the ones who established theories in philosophy, political theory, and psychoanalytic theory, which in turn were being transformed by structuralists who had their origins in Saussurean linguistics. But there were also others who criticized Saussure's theories. These were the critics who later on became poststructuralists. Attention to the role of literature and literary language was crucial to the rise of post-structuralist theory. In her writings and research, Kristeva strongly opposed the stable signification that was centred on the transformation of Saussure's concept of semiology into what was called semiotics. Structuralist semiotics advocated the objectivity of language, stating that myths, oral cultural traditions, literary texts, or any cultural text can be scientifically analysed. But this approach neglected to give attention and importance to the human subject who performs the actual analysis of a given text under consideration. All these aspects which were not taken into account by structuralist semiotics, are handled by Kristeva. Her extensive research on structuralist semiotics led to the emergence of the theory of intertextuality.

Kristeva was influenced not only by Saussure's theories but also by Bakhtin's. It is through the combination of Saussurean and Bakhtinian theories that Kristeva's notion of intertextuality emerged. In Desire in Language: A Semiotic Approach to Literature and Art, Kristeva revised and redirected Bakhtin's work in one of her most important essays: "The Bounded Texts" and also in "Word, Dialogue and Novel". In this work, she is concerned with establishing the manner in which a text is constructed, keeping in mind the knowledge and ideas that the author would have gained from his previous reading experiences. She argues that authors do not create texts from their own mind, but rather compile them from previous texts. Thus, the text becomes "a permutation of texts, an intertextuality in the space of a given text," in which "several utterances, taken from other texts, intersect and neutralize one another" (36).

She argues that the text is not an individual, isolated work but a compilation of cultural textuality. Kristeva believes that the cultural texts are made from the same textual material and cannot be separated from each other. This is basically re-phrasing of the Bakhtinian idea of the "dialogue," which established a relation between the author, work, reader, society, and history. The distinction is that Kristeva's theory paid close attention to the text, textuality, and their relation to ideologies. Bakhtin's work centres on human subjects using language in specific social situations, while Kristeva's work deals with more abstract ideas, such as text and textuality. However, both Bakhtin and Kristeva believed that texts cannot be separated from the larger cultural or social textuality out of which they are constructed. Therefore all texts contain ideological structures expressed through any given text. 
According to Kristeva, texts do not present clear and stable meanings. They are representative of society's conflict over the meaning of words. Thus intertextuality deals with the existence of a text and its role within society and history. Texts have no unity or unified meaning of their own; they are thoroughly connected to the cultural and social processes. A text's meaning is understood, in Kristeva's view, as a temporary alteration of elements with socially pre-existing meaning. Meaning then is simultaneously both 'inside' (reader's view) and 'outside' (society's influence) the text. The communication between author and reader is always paired with an intertextual relation between words and their prior existence in past texts. As Kristeva states: "any text is constructed as a mosaic of quotations; any text is the absorption and transformation of another" (66).

Flann O’Brien in his book At Swim-Two-Birds, says that every author should draw inspiration for his characters and themes from the entire corpus of existing literature, as required. He feels that the modern novel should largely be a work of references. In this regard, O’Brien states:

"A wealth of references to existing works would acquaint the reader instantaneously with the nature of each character, would obviate irksome explanations, and would effectively prelude mounte blanks, upstarts, thimble riggers and persons of inferior education from an understanding of contemporary literature. (25)

The idea that every text is made up of previous texts and reflects it through citation, allusion, use of phrases and themes of older texts, becomes the method making an intertextual study of the pragmatics of suffering in the Book of Job and The Grapes of Wrath.

\section{THE BOOK OF JOB}

It is interesting to note that the joban narrative has received more literary adaptations, artistic renderings and critical analysis than any other biblical narrative. Storytellers take to the theme of unjust or undeserved suffering. This is perhaps the most universal theme because it addresses readers on an emotional level. Regardless of culture, religion, and gender, every person undergoes some type of misery during the course of his or her lifetime. Modern and critical commentary attempts to make sense of the plight of one good, patient man and the undue suffering that he is subjected to.

The Book of Job, the authorship of which continues to be a mystery, deals with a deep-seated conflict between the integrity of God and the integrity of man. The stage is set for this conflict by the telling of a legend about Job, the pious patriarch whose ways and will are in complete accord with those of God. At this point, God makes a wager with Satan to test the limit of Job's faithfulness and his integrity towards God in the face of suffering. God grants Satan the will to do to Job as he pleases. As a result, Job loses all of his children, his wealth, health, and reputation that he had created for himself.

The only thing that Job is spared is his life, which is not worth living in the condition that he is in. Job is devastated beyond measure and is in inexplicable pain spiritually, physically, and emotionally. The shock of Job's calamities has devastated him; he prostrates himself seven days and seven nights without uttering a word to anyone. He sat among the ashes because his grief was so great, his world has collapsed, and his inherited values have been discredited. Job's wife is frustrated to see the pathetic condition of her husband who was once a prince of the land. She says, "Dost thou still retain thine integrity? Curse God, and die.” (2:9) Job turns down her advice and remains faithful to God.

Job's friends on hearing his plight come to partake in his grief and comfort him. On seeing Job they are unable to recognize their friend in the state that he is in. They do not speak anything to him during his period of mourning. Finally, 
Job is the first person to break the silence, and when he speaks he pours out from the depth of his soul. He curses the day of his birth. He wishes that he had been stillborn and had gone to Sheol. In the midst of his suffering Job cries out, inquiring as to why God permitted that suffering in his life. Job believes that God has singled him out for some unknown reason.

Job knows that he cannot argue with God, he feels he will be unable to prove his innocence, saying, "I know it is so of a truth: but how should man be just with God?” (9:2). If Job debates with God, he will be considered guilty. He does however desire to meet God and speak his innocence to God's face. Job is of the belief that God delights in witnessing his suffering while allowing evil to reign uncontrollably and that God has created him for the sole purpose of tormenting him.

To add to Job's pain, his friends Eliphaz, Bildad, and Zophar who have come to comfort and console him in his profound grief, only end up agonizing Job all the more. When Job claims he is innocent and does not deserve what he is going through, his friends claim that Job is indeed guilty and has therefore received retribution for his sins. They are annoyed by Job's persistent belief and claim that he is innocent. Their sympathy results in extreme sarcasm. They are totally apathetic to Job's loss and suffering.

Job is grieved that God is ignoring his pleas for a hearing and that in turn makes way for his friends to prove his guilt. When all had finished their accusations, God speaks to Job from out of a storm, saying: "Who is this that darkeneth counsel by words without knowledge? Gird up now thy loins like a man; for I will demand of thee, and answer thou me." (38:2-3) God does not speak to Job in a manner that is to be expected. He does not give Job any valid and convincing reasons for his suffering. Instead, God asks Job a series of rhetorical questions that serve to highlight His sovereign and divine nature. Ironically, instead of Job questioning God as he wanted to, it is God who questions him. God points out to Job his impertinent behaviour of asking God to explain the reason for his suffering. Job is made to feel very small in front of his creator. Job realizes that his questioning of God was totally inappropriate, and he despises himself and repents for his attitude and action in dust and ashes.

In the end as a reward for his endurance and integrity, God restores the life of Job and he gets back a double fold of all that he had lost. It was his will to endure suffering and his belief that he will return to his former glory enabled him to receive it.

\section{THE GRAPES OF WRATH}

Great literary works have adopted and reflected the mood of the prevailing times in which they were written. Similarly, The Grapes of Wrath was written by John Steinbeck when the Great Depression was at its devastating peak in the history of America. Steinbeck does full justice in expressing his anger and successfully searches deep down the recesses of human sorrow. The Grapes of Wrath is about the inexplicable struggle and suffering of the dispossessed Okies and Arkies in California.

Steinbeck who intends to take his readers through the gravest of human struggles starts his novel with a note of optimism by introducing the symbol of the 'turtle' which points out to the resilient nature of man to fight against odds. This is indeed a very important pragmatic aspect of suffering. The Great Depression lasted from 1929 till 1939 as a result of the Dust Bowl. The stock market crashed heavily beginning in 1929. Extreme dryness of the weather and lack of rain left the crops rotting in the fields. Farmers were placated from their farms by "the bank" that drove them away in order to see some profit. This grave situation led to the mass migration of people from their farmland to move to the cities for survival. 
The Joad family in the novel bears the brunt of the Dust Bowl and the resultant loss and pain to a great extent. Tom Joad the young delinquent is back home after serving a four years term in prison for charges of murder. His arrival is perfectly timed to join his family in their migration to California. Tom and his brothers Noah and Al skilfully repair an old truck that carries the entire brood on their exodus. The youngest of the family Ruthie and Winfield are at most times oblivious to the great struggle that the entire family is going through. The family's loss of their land is followed by the loss of their grandpa and grandma. Their inability to give them a decent burial is a greater pain than their loss itself.

The Joads take every effort to stay strong and united in the face of adversity and loss. Loss of property, loss of loved ones, and most importantly, loss of their dignity was the worst of all. Their dignity is shattered as they are compelled to sell all their possessions and their memories too that were attached to their belongings. The harrowing exodus is constantly filled with fear over their meagre finances and hapless condition of their vehicles. The Joads and the other dispossessed immigrants were looked down upon as unwelcome and a threat by the inhabitants of California. Finding a safe place to stay with basic amenities becomes a dream. Camp managers harass and humiliate the hordes of immigrants moving in. The only thing that keeps the immigrants going is their faith in community strength and unity.

The Joad family strongly believes in staying together. Ma Joad acts as the fulcrum of the family and roars like a protective lioness to save her brood in the face of imminent danger. She has faith that they will overcome their obstacles and go forward but will never step back whatsoever. This indomitable determination of Ma can be seen when she says, "We're the people that Live... we're the people - we go on" (TGOW 293). However, the harsh and diabolic reality of the Dust Bowl stings them in various forms and intensities. The departure of Noah and Connie leaves them feeling betrayed. Yet they move on. There is short respite in the form of little jobs they get. This however is transient. Even when they find jobs as cotton pickers, they only anticipate the imminent danger of losing it because of the rains.

The last of the loss that the Joads face is the stillborn baby of Rosasharn. It seemed as if life carried a scythe that severed the little joy and hope that the Joads had of bouncing back. Strangely though, the Joads are still determined to fight it against all odds. They are undeterred by all that they have faced and experienced. They want to make the best use of their suffering to be of some use to a fellow human being. Rosasharn accomplishes this exemplary feat by feeding her breast milk to a dying man in the barn.

\section{CONCLUSIONS}

Human suffering especially the undeserved continues to be an intriguing phenomenon. Several works of literature have taken from the strands of innocent or undeserved suffering to weave remarkable canons that have impressed readers. Suffering is an aspect of life that cannot be limited to any particular point of time but has made its arbitrary presence since the evolution of mankind. This is what has been observed in the intertextual study of the Book of Job and John Steinbeck's TheGrapes of Wrath. The characters in both the narratives belong to different periods of time and suffer for different reasons. However, there seems to be a similarity in their suffering and the resultant consequences.

Job at the beginning of the text lost everything he had. His children, his property, his health, his relationship with family and friends, and finally his dignity and honour. He was considered as good for nothing and worst of all a sinner. He suffered extreme reproach when his friends condemned him of having sinned against God. Job fights back with his arguments to ascertain his innocence. He is not willing to accept the accusations and give up. He is very confident that God will vindicate and he will come forth as gold and says, "But He knows the way that I take; when He has tried me, I shall 
come forth as gold." (Job 23:10) Job does emerge innocent when God vindicates him. Job restores all that he had lost.

The Joads, like Job, lose everything. They are stripped by ruthless bank owners of their land and cast away like filth. They begin their exodus in search of a livelihood and in the process face more losses and more humiliation. They are determined like Job to fight against adversity and tenaciously hold on to dear life with the faith that they will emerge victors. Steinbeck depicts the Joads as having conquered and overcome suffering, when Rosasharn instead of feeling bitter and resentful after giving birth to a stillborn child, feeds a dying man in the barn with her breast milk.

These exhibits of determination, courage, and resilience are seen in Job and the characters of Steinbeck's The Grapes of Wrath. These qualities in them prove the pragmatism of suffering that suffering need not necessarily break a person, but can make a person evolve stronger and resilient if they endure suffering with hope and confidence in bouncing back. Another pragmatic aspect of suffering that can be observed in the two narratives is that evil is integral to bring out the indomitable nature of man into action. The experience of Job and the Joads is a microcosm of innocent or undeserved suffering throughout the world.

\section{REFERENCES}

1. The Bible. (1985) New King James Version. New York: Thomas Nelson, Edn. Print

2. Steinbeck, J. (2017). The Grapes of Wrath. Penguin Books. Print

3. AMINO, KAORU. "CONCEPTUALIZING THE JAPANESE AND AMERICAN OCCUPATIONAL MEETING: AN EXAMINATION OF THE PRAGMATIC USAGE OF ENGLISH AND JAPANESE DISCOURSE MARKERS “OH” AND “ATT"." International Journal of Communication and Media Studies (IJCMS) 10.1, Feb 2020, 1-16

4. Kristeva, J. (1980). Desire in Language: A Semiotic Approach to Literature and Art. New York: Columbia University Press. Print

5. O'Brien, F. At-Swim-Two-Birds. Harmondsworth: Penguin. Print

6. SEN, DILIP KUMAR. "LANGUAGE TEACHING IN TECHNICAL INSTITUTE." FOCUS AND SCOPE: 39. International Journal of English and Literature (IJEL), Jun 2014, 39-42

7. Sivakumar, N., and N. Tamilselvan. "Newspaper Reading Habits of College students: A case study of Kalaignar Karunanidhi Institute of Technology." International Journal of Library science and Research 5.2 (2015): 31-36.

8. Ihuah, Paulinus Woka. "Appraisal Methods In Mutually Exclusive Development Projects: A Pragmatic Analysis Of Alternative Technique." International Journal of Applied and Natural Sciences (IJANS). International Academy of Science Engineering and Technology. ISSN (P) (2014): 2319-4014.

9. KOUKPOSSI, Albert Omolegbé. "A PRAGMATIC ANALYSIS OF DONALD TRUMP'S REMARKS AT WOMEN'S EMPOWERMENT PANEL." International Journal of Linguistics and Literature (IJLL) 9.6, Oct-Nov 2020; 43-54 